Check for updates

Cite this: RSC Adv., 2018, 8, 14898

\title{
Analysis of binding properties of pathogens and toxins using multivalent glycan microarrays $\uparrow$
}

\author{
Hyoung Sub Kim, Ji Young Hyun, Seong-Hyun Park and Injae Shin (D) * \\ Pathogens infect hosts often through initial binding of their cell surface lectins to glycans expressed on the \\ exterior of host cells. Thus, methods to evaluate the glycan-binding properties of pathogens are of great \\ importance. Because of the multivalent nature of interactions of pathogens with glycans, the ability to \\ assess the glycan density-dependent binding of pathogens is particularly important. In this study, we \\ developed a facile technique to construct multivalent carbohydrate microarrays through immobilization \\ of unmodified glycans on multivalent hydrazide-derivatized glass surfaces. This immobilization strategy \\ does not require the use of multivalent glycoconjugates, which are typically prepared by using multistep \\ sequences. The results of analysis of microarray images, obtained after incubation of multivalent glycan \\ microarrays with cholera toxin B and pathogens such as uropathogenic E. coli and $H$. pylori, show that \\ the binding affinities of toxins and pathogens for glycans are highly glycan density-dependent. \\ Specifically, toxins and pathogens bind to glycans more strongly as the valency of the glycans on the \\ microarrays is increased from 1 to 4 . It is anticipated that the newly developed immobilization method \\ will be applicable to the preparation of multivalent carbohydrate microarrays that are employed to \\ evaluate multivalent glycan binding properties of a variety of pathogens and toxins.
}

Received 9th February 2018

Accepted 15th April 2018

DOI: $10.1039 / \mathrm{c} 8 \mathrm{ra01285g}$

rsc.li/rsc-advances understanding of the nature and consequence of glycanassociated recognition by pathogens and toxins.

Carbohydrate microarrays, which consist of various glycans densely and orderly immobilized on solid surfaces, have been widely employed for high-throughput analysis of glycanassociated recognition events. ${ }^{6-9}$ In addition, this microarray technology has been utilized for assessing substrate specificities of glycosyltransferases, determining protein-glycan interactions quantitatively, and identifying functional glycans. ${ }^{10,11}$ Furthermore, carbohydrate microarrays have been used to assess binding properties of whole viruses and bacteria. ${ }^{12}$ Also, these microarrays containing varying glycan densities have been utilized to study the glycan density-dependent binding properties of lectins..$^{13}$ In spite of this high level of research activity, the microarray-based technology has not been employed to analyze density-dependent binding of bacteria and toxins to glycans. In the study described below, we developed a facile method to construct multivalent carbohydrate microarrays, possessing various glycans that have valencies ranging from 1 to 4 . Moreover, these microarrays were employed to demonstrate that binding of bacterial pathogens and toxins is highly glycan density-dependent.

\section{Results and discussion}

Several types of carbohydrate microarrays, containing multivalent glycans such as neoglycoproteins/neoglycopeptides, glycodendrimers, peptide nucleic acid-conjugated glycans and DNA- 

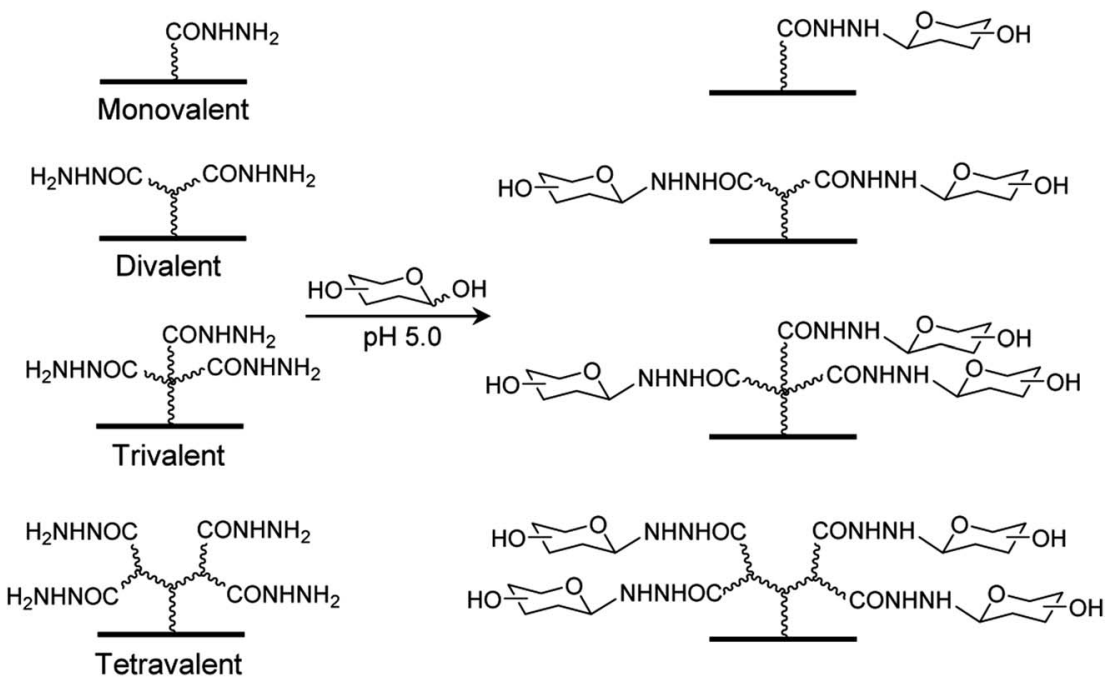

Fig. 1 Construction of carbohydrate microarrays containing mono- and multivalent glycans by immobilizing free glycans on surfaces derivatized with mono-, di, tri- and tetravalent hydrazides.

linked glycans with varying glycan densities, have been created previously to evaluate glycan density-dependent binding of lectins. ${ }^{13}$ However, preparation of the multivalent glycoconjugates used to construct these microarrays require multistep sequences. To avoid the time-consuming and difficult synthesis of multivalent glycoconjugates, we took advantage of an earlier observation showing that unmodified mono-, di-, oligo- and polysaccharides are covalently and site-specifically immobilized on hydrazide-derivatized surfaces. ${ }^{14,15}$ Accordingly, in this effort we developed a new, facile immobilization protocol for construction of mono- and multivalent carbohydrate microarrays, in which unmodified glycans are linked to mono-, di-, tri- and tetravalent hydrazide-derivatized glass slides (Fig. 1).

The linkers required for modification of glass slides with multivalent hydrazides were synthesized by using pathways shown in Scheme 1. Briefly, synthesis of di- and tri-t-butyl ester containing linkers $\mathbf{7}$ and $\mathbf{8}$, containing primary amine groups required for attachment to glass surfaces, was initiated by reactions of 1 and 2 with $t$-butyl acrylate under basic conditions, respectively. The adducts 3 and 4 were reacted with 2-(2-(2-(2azidoethoxy)ethoxy)ethoxy)acetic acid to generate the respective amide coupled products 5 and $\mathbf{6}$. Reduction of the azide groups in 5 and $\mathbf{6}$ by catalytic hydrogenation over Pd/C produced the corresponding amines 7 and 8. In addition, the tetra-t-butyl ester containing linker $\mathbf{1 0}$ was prepared by sequential removal of $t$-butyl in $\mathbf{5}$, the amide coupling reaction of the resulting diacid $\mathbf{5}^{\prime}$ with 3 to yield azide 9 , and catalytic hydrogenation.

Next, glass surfaces were modified with mono-, di, tri- and tetravalent hydrazides. For this purpose, epoxide-coated glass slides were converted to $N$-hydroxysuccinimide (NHS) ester derivatized slides (Fig. 2), ${ }^{16}$ which were then treated with hydrazine to generate monovalent hydrazide-coated glass slides. In addition, the NHS ester-modified glass slides were

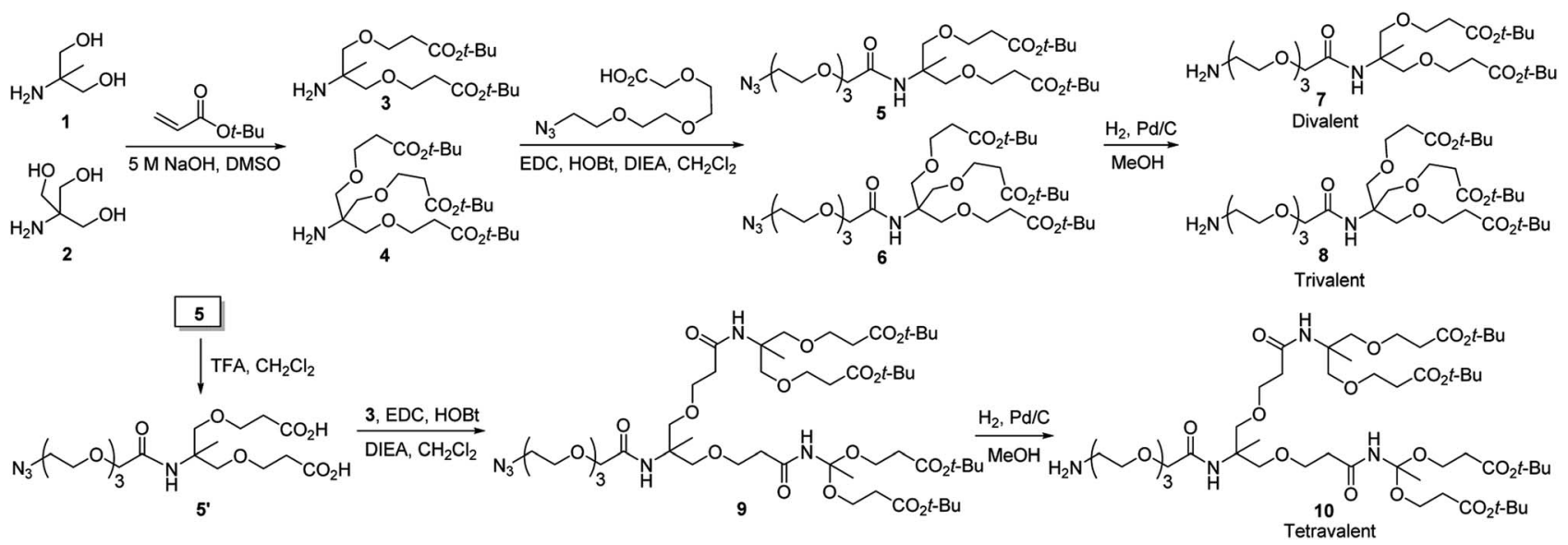

Scheme 1 Routes for synthesis of di-, tri- and tetravalent linkers 7, 8 and 10 used for modification of glass slides with multivalent hydrazides. 


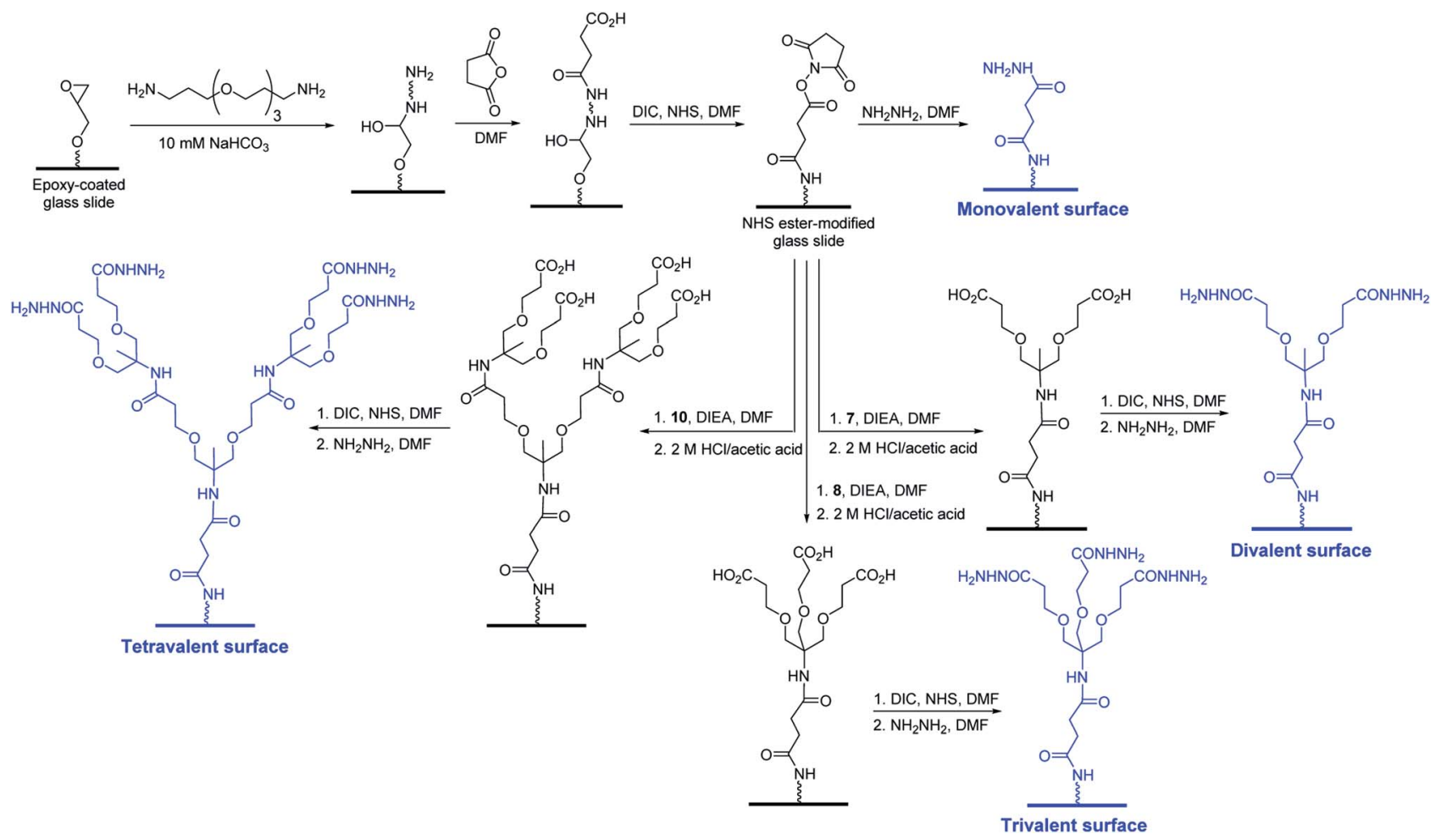

Fig. 2 Construction of mono- and multivalent hydrazide-modified glass slides.

individually treated with $\mathbf{7}, \mathbf{8}$ and $\mathbf{1 0}$ followed by removal of $t$ butyl groups under acidic conditions to generate the respective di-, tri- and tetravalent acid modified slides. Finally, the acid groups on the surfaces of each slide were converted to NHS esters, which were then reacted with hydrazine to generate the target di, tri- and tetravalent hydrazide-modified slides.



18. NeuNAc $\alpha 2,3 \mathrm{Gal} \beta 1,4 \mathrm{GIC}$

19. NeuNAc $\alpha 2,3 \mathrm{Gal} \beta 1,4 \mathrm{GICNAC}$

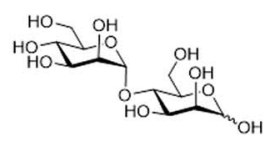

15. Man $\alpha 1,4$ Man

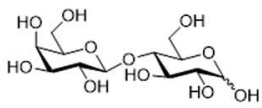

16. Galß1,4Glc (Lac)

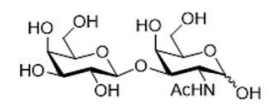

17. Gal $\beta 1,3$ GalNAc

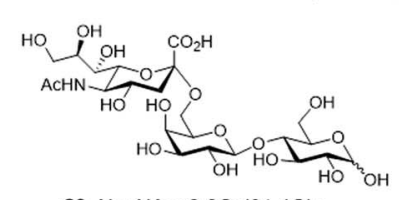

20. NeuNAc $\alpha 2,6 \mathrm{Gal} \beta 1,4 \mathrm{Glc}$

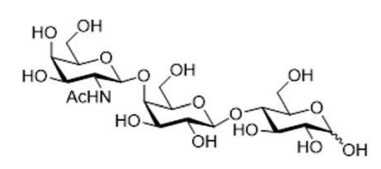

21. GalNAc $\beta 1,4 \mathrm{Gal} \beta 1,4 \mathrm{Glc}$

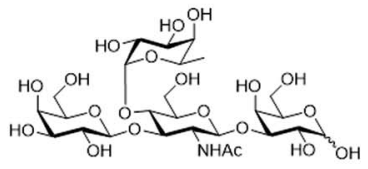

22. Gal $\beta 1,3(F u c \alpha 1,4)$ GlcNAc $\beta 1,3 \mathrm{Gal}\left(\operatorname{Le}^{\mathrm{a}}\right)$

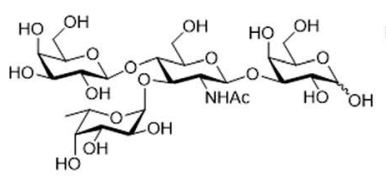

23. Gal $\beta 1,3$ (Fuc $\alpha 1,3)$ GICNAc $\beta 1,3 \mathrm{Gal}$ $\left(\mathrm{Le}^{\mathrm{x}}\right)$

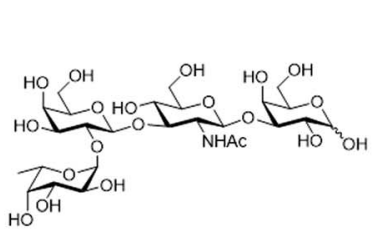

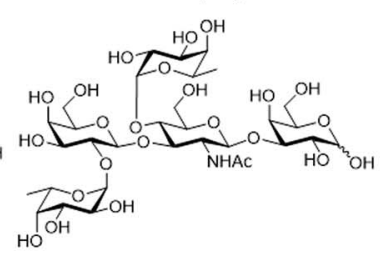

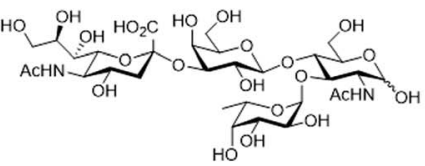

24. NeuAc $\alpha 2,3$ Gal $\beta 1,4$ (Fuc $\alpha 1,3)$ GlcNAc (Sialyl Le ${ }^{x}$ )

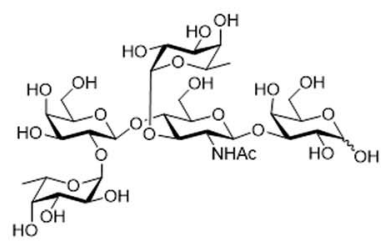

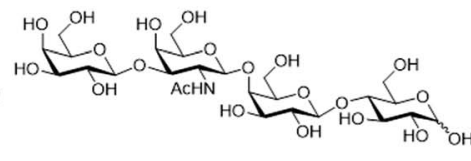

25. Gal $\beta 1,3 \mathrm{GalNAc} \beta 1,4 \mathrm{Gal} \beta 1,4 \mathrm{Glc}$ (Asialo GM1)

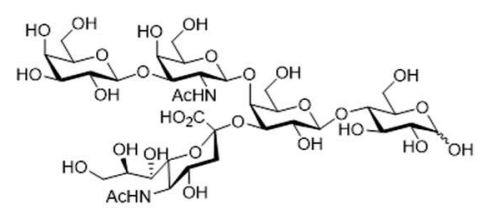

26. Fuc $\alpha 1,2 \mathrm{Gal} \beta 1,3 \mathrm{GlcNAc} \beta 1,3 \mathrm{Gal}$ 27. Fuc $\alpha 1,2 \mathrm{Gal} \beta 1,3(\mathrm{Fuc} \alpha 1,4) \mathrm{GlcNAc} \beta 1,3 \mathrm{Gal}$ 28. Fuc $\alpha 1,2 \mathrm{Gal} \beta 1,4(\mathrm{Fuc} \alpha 1,3) \mathrm{GlcNAc} \beta 1,3 \mathrm{Gal}$ 29. Gal $\beta 1,3 \mathrm{GalNAc} \beta 1,4(\mathrm{NeuNAc} \alpha 2,3) \mathrm{Gal} \beta 1,4 \mathrm{Glc}$ (H1) $\left(\mathrm{Le}^{\mathrm{b}}\right)$ $\left(\operatorname{Le}^{\mathrm{y}}\right)$

Fig. 3 Chemical structures of glycans used for construction of mono- and multivalent carbohydrate microarrays. 


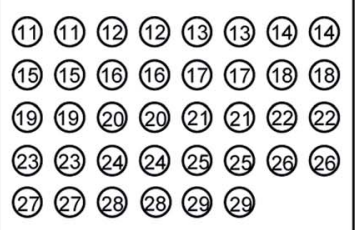

Layout of carbohydrate spots

A
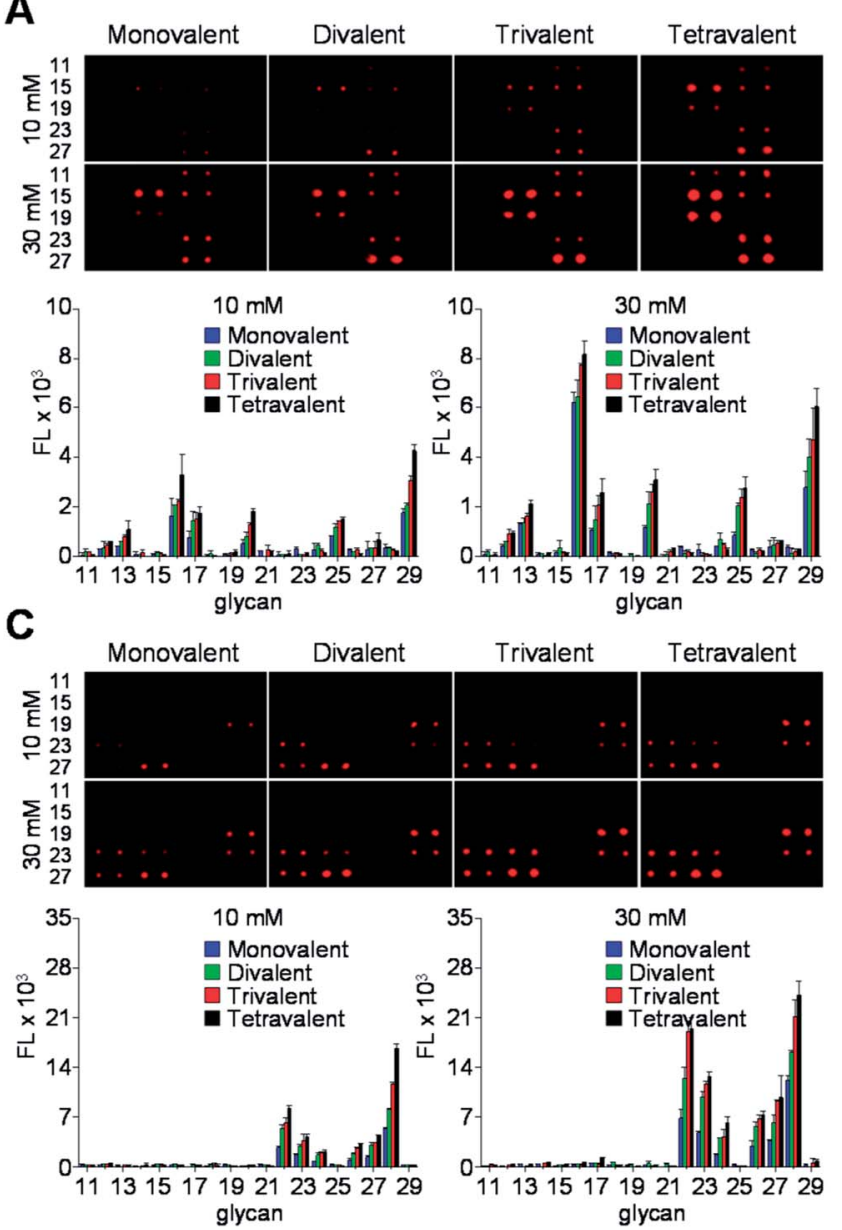

B
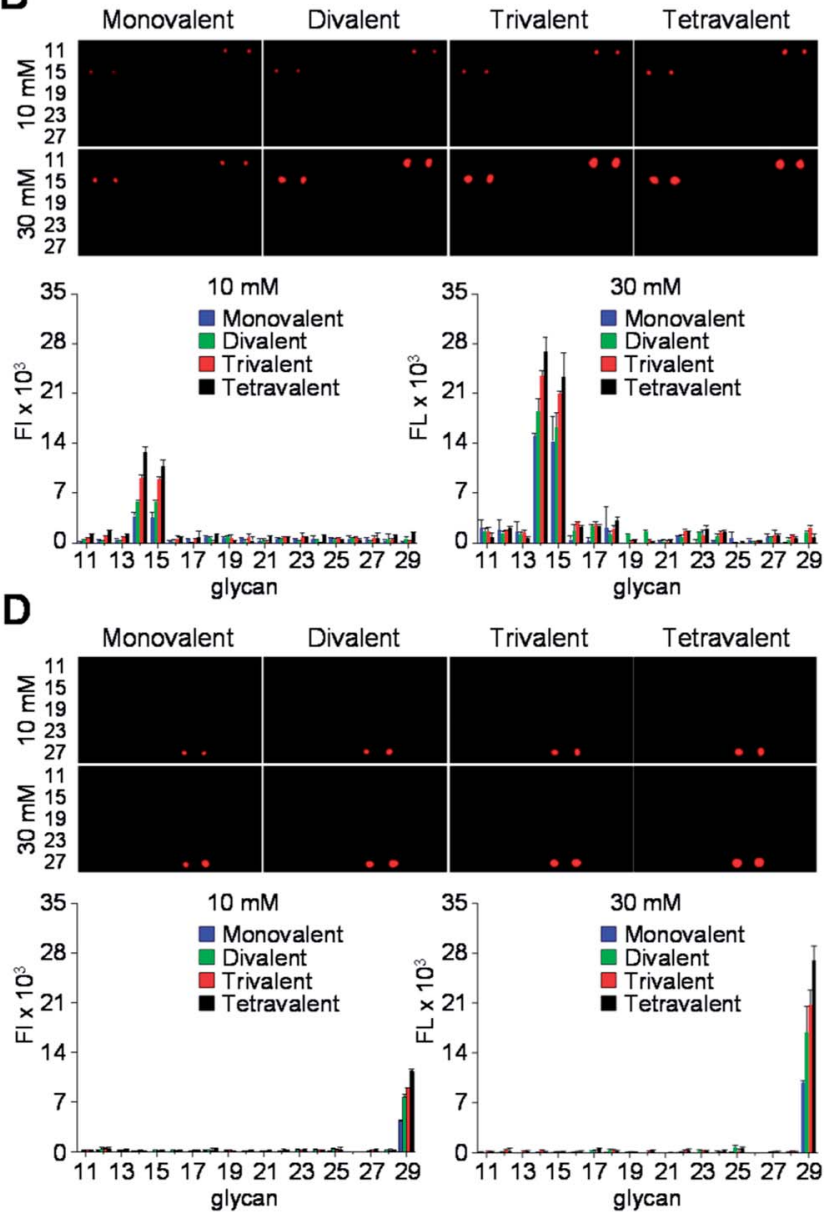

Fig. 4 (Upper images) Fluorescence images of mono- and multivalent carbohydrate microarrays (immobilization concentration of free glycans: $10 \mathrm{mM}$ and $30 \mathrm{mM}$ ) after probing with (A) Cy3-RCA 120 , (B) Cy3-ConA, (C) Cy3-AA and (D) Cy3-CT-B for $1 \mathrm{~h}$. The distance between centers of adjacent spots is $250 \mu \mathrm{m}$. (Bottom graphs) Fluorescence intensities (arbitrary unit) of carbohydrate microarrays (error bar: mean $\pm \mathrm{s} . \mathrm{d}$., $n=3$ ).

Carbohydrate microarrays containing mono- and multivalent glycans were prepared by printing nineteen unmodified sugars (1.0 nL, 10 and $30 \mathrm{mM}$ of mono- (11-13), di- (14-17) and oligosaccharides (18-29)) on mono-, di-, tri- and tetravalent hydrazide-coated glass slides by using an automatic pin-type microarrayer (Fig. 3). ${ }^{14}$ To demonstrate that the glycans were successfully immobilized on the mono- and multivalent hydrazide-modified surfaces, the microarrays were incubated with Cy3-labeled plant lectins including Ricinus communis agglutinin I ( $\mathrm{RCA}_{120}$, a Gal/GalNAc binding lectin), Concanavalin $A$ (ConA, an $\alpha$-Man/ $\alpha$-Glc binding lectin) and Aleuria aurantia lectin (AA, a Fuc binding lectin). The results of microarray image analysis showed that the glycans on the microarrays displayed lectin binding profiles that were in agreement with those observed in previous studies (Fig. 4A-C)..$^{14,17,18}$ Specifically, $\mathrm{RCA}_{120}$ recognized glycans containing Gal/GalNAc (binding order: Gal < GalNAc < Galß1,3GalNAc $\leq$ asialo-GM1 < NeuNAc $\alpha 2,6$ Lac $<$ GM1 < Lac),${ }^{\mathbf{1 4}, 18}$ ConA bound to Man $\alpha 1,2$ Man and Man $\alpha 1,4$ Man with similar affinities, ${ }^{\mathbf{1 4}}$ and AA recognized Fuc containing glycans (binding order: sialyl Le $\mathrm{X}^{\mathrm{x}}<\mathrm{H} 1<\mathrm{Le}^{\mathrm{b}}<\mathrm{Le}^{\mathrm{x}}<$ $\left.\mathrm{Le}^{\mathrm{a}}<\mathrm{Le}^{\mathrm{y}}\right) \cdot{ }^{14,17,18}$ The observations also showed that lectin binding to glycans becomes stronger as the valency is increased, and that tetravalent glycans immobilized using $10 \mathrm{mM}$ concentrations bind to lectins with similar affinities as do monovalent glycans immobilized using $30 \mathrm{mM}$ concentrations. 
A

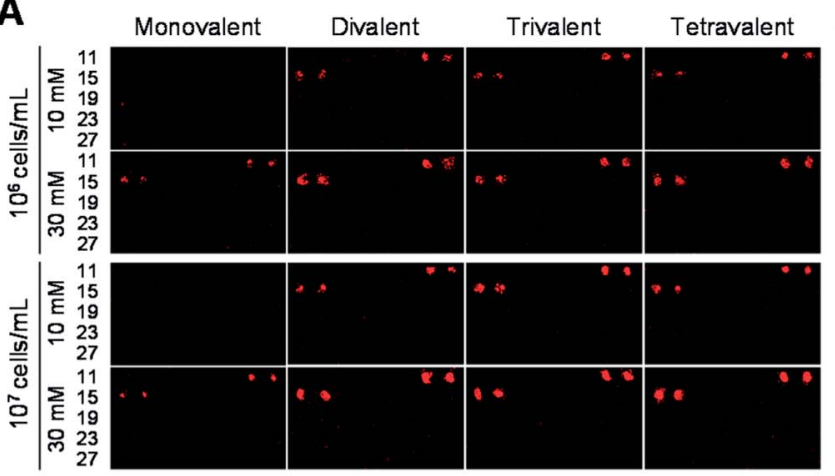

$10^{6}$ cells $/ \mathrm{mL}$

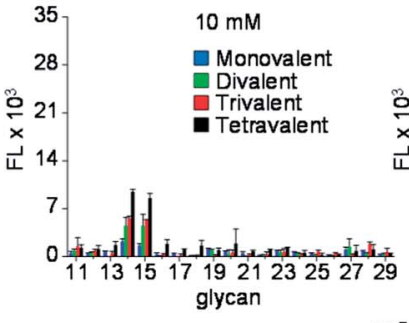

$10^{7} \mathrm{cells} / \mathrm{mL}$
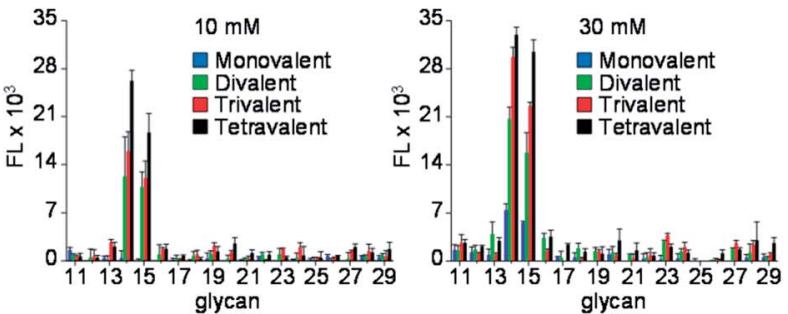

B

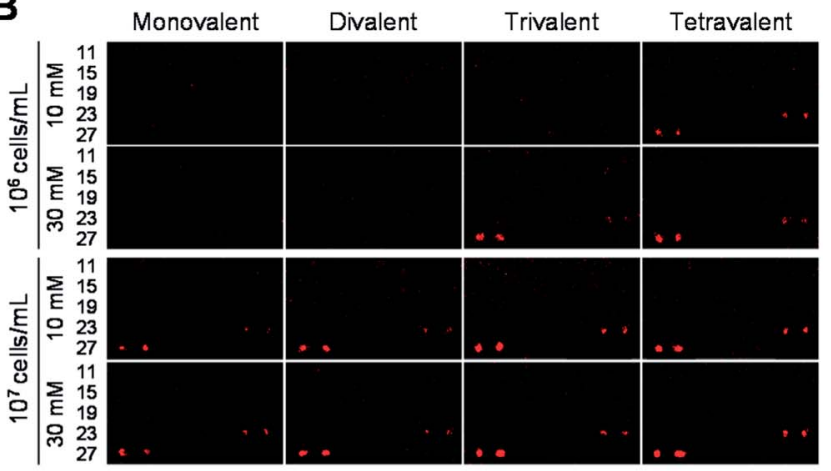

$10^{6} \mathrm{cells} / \mathrm{mL}$
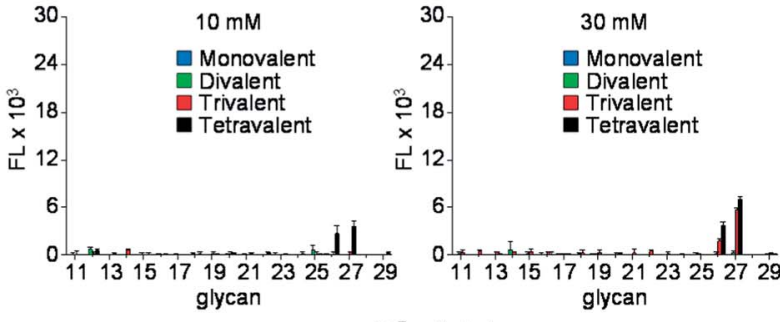

$10^{7} \mathrm{cells} / \mathrm{mL}$
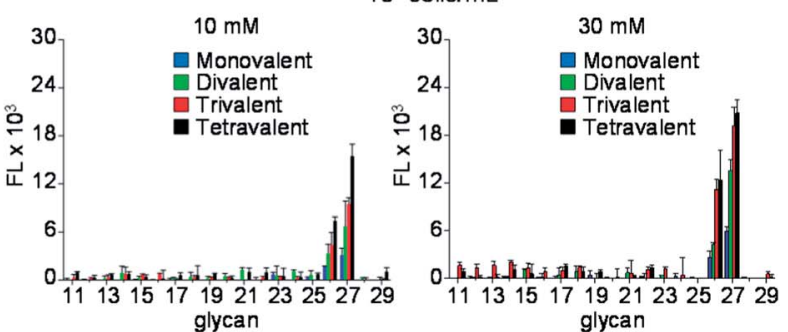

Fig. 5 (Upper images) Fluorescence images of mono- and multivalent carbohydrate microarrays treated with SYTO 83-labeled (A) E. coli ORN178 in PBS buffer (pH 7.4) containing $0.1 \%$ BSA, $1 \mathrm{mM} \mathrm{CaCl}$ and $1 \mathrm{mM} \mathrm{MnCl}_{2}$ and (B) H. pylori $\mathrm{J} 99$ in TBS buffer $(50 \mathrm{mM} \mathrm{Tris-Cl,} 150 \mathrm{mM} \mathrm{NaCl}$, $\mathrm{pH}$ 7.4) containing $0.1 \%$ BSA. The distance between centers of adjacent spots is $250 \mu \mathrm{m}$. (Bottom graphs) Fluorescence intensities (arbitrary unit) of carbohydrate microarrays (error bar: mean \pm s.d., $n=3$ ). The layout of carbohydrate spots on glass slides is shown in Fig. 4 .

The findings indicate that glycans are successfully attached to mono- and multivalent hydrazide-coated glass slides.

Studies were then performed to evaluate binding of cholera toxin B (CT-B) to glycans on the microarray. The Gram-negative Vibrio cholerae colonizes the small intestine and is the main pathogen causing life-threatening acute diarrhoea (cholera). This pathogen secrets cholera toxin (CT), which is composed of two proteins including the monomeric subunit A (CT-A) and the pentameric subunit B (CT-B). ${ }^{19}$ The released toxin adheres to host cells by binding of CT-B to GM1-ganglioside, which is expressed in various cell types including epithelial cells of the gut and immune cells. ${ }^{20}$ Thus, studies of the binding properties of CT-B to multivalent glycans is highly significant. To date, binding of CT-B to multivalent glycans has been probed using an SPR technique ${ }^{21}$ and carbohydrate microarrays. ${ }^{22}$ However, multivalent interactions between CT-B and glycans have not been assessed thus far. To address this issue, glycan microarrays containing glycans 11-29 with a valency ranging from 1 to 4 were incubated with Cy3-labeled CT-B for $1 \mathrm{~h}$. As shown in Fig. 4D, CT-B bound to GM1-oligosaccharide (Galß1,3GalNAc $\beta 1,4($ NeuNAc $\alpha 2,3)$ Gal $\beta 1,4 \mathrm{Glc}$ ) strongly but did not interact

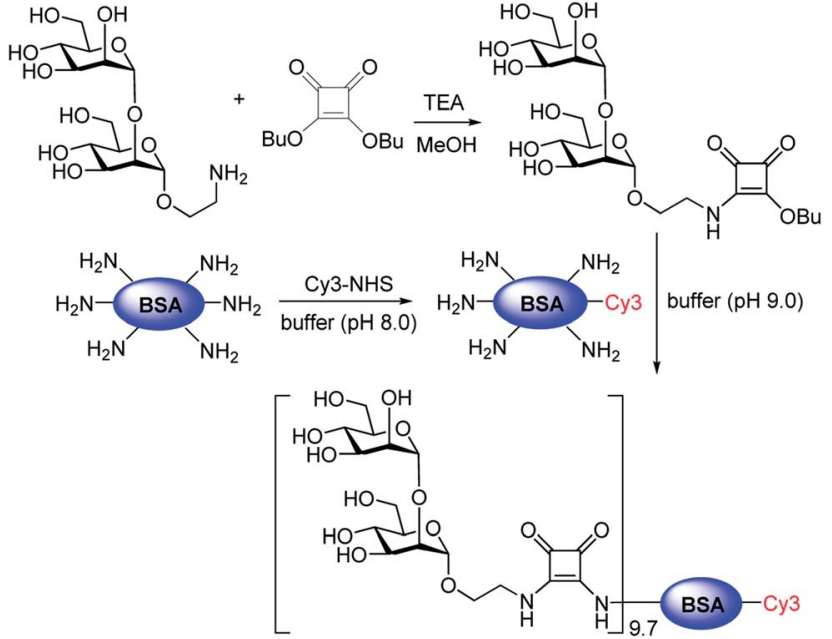

Fig. 6 Preparation of the Cy3-BSA-Mana1,2Man conjugate. The ratio of Man 1,2 Man conjugation to Cy3-BSA was determined by MS analysis (see ESI† for more details). 


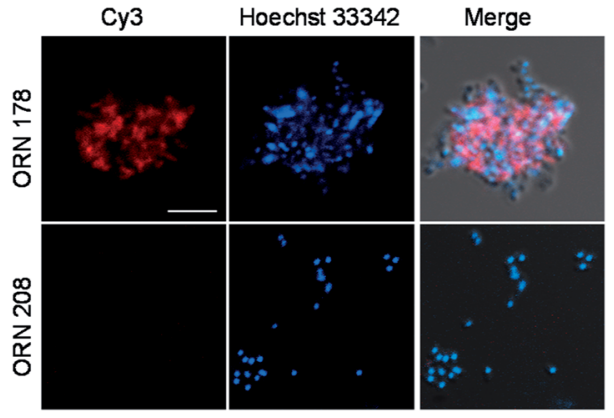

Fig. 7 Binding of Cy3-BSA-Mana1,2Man to E. coli ORN178 and ORN208. E. coli cells, pretreated with $1 \mu \mathrm{M}$ Hoechst 33342 for 5 min, were incubated with $200 \mu \mathrm{g} \mathrm{mL}^{-1}$ of Cy3-BSA-Man 1 1,2Man for $1 \mathrm{~h}$. Cell images were obtained by using confocal microscopy (scale bar $=$ $5 \mu \mathrm{m})$.

with the other glycans..$^{21-23}$ The results also showed that CT-B bound to glycans more tightly as the glycan valency was increased from 1 to 4 and that recognition of the tetravalent GM1-oligosaccharide immobilized at a concentration of $10 \mathrm{mM}$ by CT-B was comparable to binding of CT-B to a monovalent GM1-oligosaccharide immobilized using a concentration of $30 \mathrm{mM}$.

Next, the glycan microarrays were applied to study of binding of pathogens, uropathogenic Escherichia coli and Helicobacter pylori, to mono- and multivalent glycans. Uropathogenic E. coli cells adhere to the urinary tract of humans for colonization and infection via a process that is mediated by $\mathrm{P}$, Type $1, \mathrm{~S}$ and F1C fimbriae. ${ }^{24}$ Type 1 fimbriae are the most popular among fimbriae generated by uropathogenic E. coli and are important virulence factors for infection in the urinary tract. FimH, the Type 1 fimbrial adhesin of uropathogenic $E$. coli, is involved in adhesion to the high-mannosylated glycoprotein receptors in bladder epithelium..$^{25}$ Based on these observations, we assessed the binding properties of the $E$. coli ORN178 strain expressing FimH. For this purpose, E. coli ORN178 (cell density: $10^{6}$ and $10^{7}$ cells per $\mathrm{mL}$ ) along with E. coli ORN208 lacking FimH as a negative control were first treated with SYTO 83 for cell staining and then applied to mono- and multivalent glycan microarrays. Bovine serum albumin (BSA, 0.1\%) was added to suspensions of the bacterial cells to avoid nonspecific adhesion of pathogens to solid surfaces. As shown in Fig. 5A and $S 1, \dagger$ the E. coli ORN178 strain bound to mannobioses 14 (Man $\alpha 1,2 \mathrm{Man})$ and 15 (Man $\alpha 1,4$ Man) with similar affinities, whereas the E. coli ORN208 strain did not bind to these glycans. ${ }^{14}$ In addition, microarrays incubated with bacteria with cell density of $10^{7}$ cells per $\mathrm{mL}$ exhibited higher fluorescence intensity than those treated with lower cell density $\left(10^{6}\right.$ cells per $\left.\mathrm{mL}\right)$. Furthermore, the $E$. coli ORN178 strain bound more strongly to mannobioses 14 and 15 as the glycan valency was increased from 1 to 4 .

To obtain additional evidence of binding of $E$. coli to mannobioses, we prepared the Cy3-labeled BSA-Man $\alpha 1,2 \mathrm{Man}$ conjugate which had been previously successfully utilized to detect the mammalian cell-surface lectin (Fig. 6 and S2 $\dagger$ ) ${ }^{15} E$. coli ORN178 and ORN208 strains were then incubated with the glycoconjugate for $1 \mathrm{~h}$. The results of analysis of cell images obtained using confocal microscopy showed that the BSAMana1,2Man conjugate bound to $E$. coli ORN178 but not to $E$. coli ORN208, a finding which matches that made in the microarray study (Fig. 7).

The binding properties of $H$. pylori expressing BabA to monoand multivalent glycans on microarrays were evaluated next. $H$. pylori colonizes the human stomach and is one of the most widespread infectious pathogens that promotes the onset of several gastrointestinal diseases, such as chronic gastritis, peptic ulcer disease and gastric cancer. ${ }^{26} \mathrm{H}$. pylori frequently expresses cell-surface adhesins that bind to specific host cell glycans, as exemplified by the well-characterized blood group antigen-binding adhesin (BabA). In this case, infection of hosts by $H$. pylori is initiated by the interaction of BabA with $\mathrm{Le}^{\mathrm{b}}$ present in the gastric mucosa. ${ }^{26,27}$

Expression of BabA in the two H. pylori strains, J99 and 26695, was first examined by using reverse transcription-
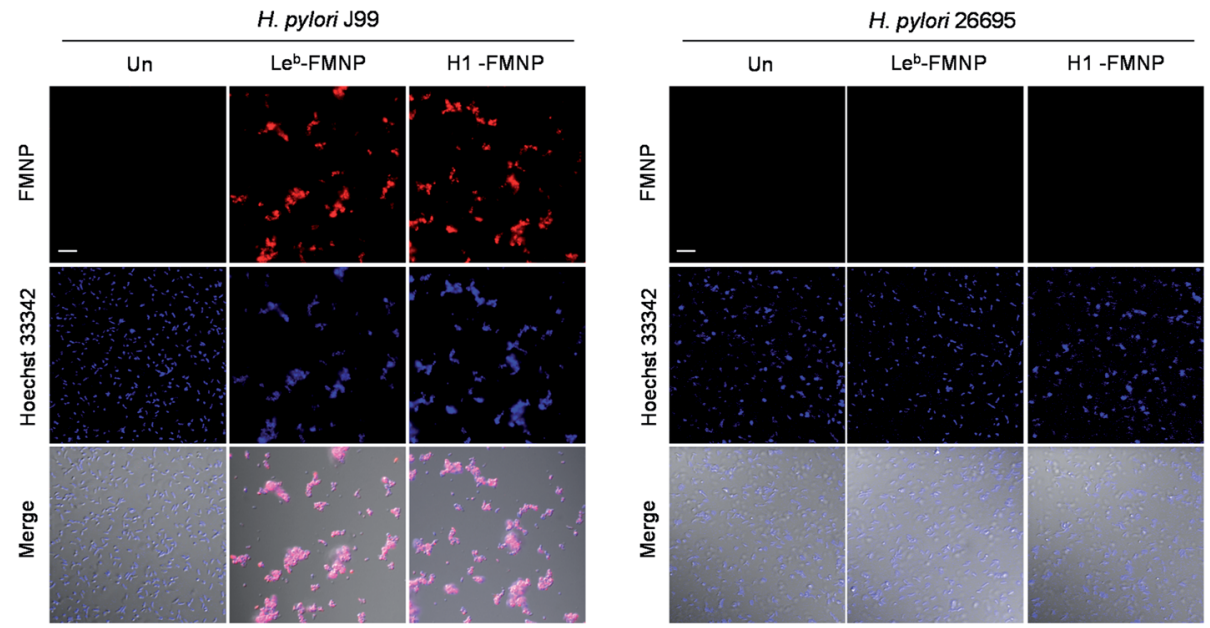

Fig. 8 Binding of glyconanoparticles to H. pylori $J 99$ and 26695 strains. H. pylori 199 and 26695 cells, pretreated with $1 \mu M$ Hoechst 33342 for $5 \mathrm{~min}$, were incubated with $100 \mu \mathrm{g} \mathrm{mL} \mathrm{m}^{-1}$ of glyconanoparticles for $1 \mathrm{~h}$. Cell images were obtained by using confocal microscopy (scale bar $=10$ $\mu \mathrm{m})$. 
polymerase chain reaction (RT-PCR). The results showed that the H. pylori J99 strain produced a BabA gene but $H$. pylori 26695 strain did not (Fig. S3†). ${ }^{27}$ Mono- and multivalent glycan microarrays were then incubated with SYTO 83-labeled $H$. pylori J99 strain (cell density: $10^{6}$ and $10^{7}$ cells per $\mathrm{mL}$ ) containing $0.1 \%$ BSA, along with the H. pylori 26695 strain as a control. The results of microarray image analysis showed that the $H$. pylori J99 strain adhered to H1 (26, Fuc $\alpha 1,2 \mathrm{Gal} \beta 1,3 \mathrm{GlcNAc} \beta 1,3 \mathrm{Gal})$ and $\operatorname{Le}^{\mathrm{b}}$ (27, Fuc $\alpha 1,2 \mathrm{Gal} \beta 1,3$ (Fuc $\left.\alpha 1,4\right)$ GlcNAc $\left.\beta 1,3 \mathrm{Gal}\right)$ with different binding affinities (Fig. 5B). Specifically, the H. pylori J99 strain bound to $\mathrm{Le}^{\mathrm{b}}$ more strongly than $\mathrm{H} 1$, a finding which is consistent with results from studies using purified $\mathrm{BabA}\left(K_{\mathrm{d}}=\right.$ $252 \mu \mathrm{M}$ for $\mathrm{Le}^{\mathrm{b}}$ and $K_{\mathrm{d}}=617 \mu \mathrm{M}$ for $\left.\mathrm{H} 1\right){ }^{28}$ The pathogen also bound to 26 and 27 in a cell density- and glycan densitydependent manner. However, H. pylori J99 did not recognize the other glycans tested and the H. pylori 26695 strain did not adhere to any of these glycans (Fig. S4 $\dagger$ ).

Confirmatory evidence for binding of H. pylori $\mathrm{J} 99$ to $\mathrm{Le}^{\mathrm{b}}$ and $\mathrm{H} 1$ was gained in a study using fluorescent magnetic nanoparticles $\left(100 \mu \mathrm{g} \mathrm{mL} \mathrm{m}^{-1}\right)$ conjugated with $\mathrm{Le}^{\mathrm{b}}$ and $\mathrm{H} 1$ which had been previously successfully employed to detect $H$. pylori J99. ${ }^{27}$ The glyconanoparticles were incubated for $1 \mathrm{~h}$ with $H$. pylori J99, which was pretreated for 5 min with $1 \mu \mathrm{M}$ Hoechst 33342 for bacterial cell staining. As control experiments, H. pylori 26695 strain was incubated with $\mathrm{Le}^{\mathrm{b}}$ - and H1-conjugated nanoparticles under the same conditions. Analysis of cell images obtained using confocal microscopy showed that $\mathrm{Le}^{\mathrm{b}}$ - and H1glycoconjugated nanoparticles bound to BabA expressing J99 but not to BabA lacking 26695 (Fig. 8). The findings are consistent with observations made in the microarray study.

\section{Conclusions}

In the investigation described above, we developed a facile and efficient method to prepare multivalent glycan microarrays, in which free glycans are immobilized on multivalent hydrazidecoated surfaces. This protocol does not require multivalent glycoconjugates that are normally prepared by using multistep pathways. By utilizing the glycan microarrays, we observed that the binding affinities of toxins and pathogens for glycans are highly glycan density-dependent. We also found that immobilization concentrations of glycans for tight binding of toxins and pathogens can be reduced from $30 \mathrm{mM}$ to $10 \mathrm{mM}$ when microarrays containing tetravalent glycans are used. To our knowledge, this is the first time that glycan microarray have been applied to analyze the density dependency of glycan binding by pathogens and toxins. We believe that the results of this effort have provided valuable information about the design and preparation of multivalent carbohydrate microarrays and about how they can be utilized for functional studies of pathogens and pathogenic proteins.

\section{Conflicts of interest}

There are no conflicts to declare.

\section{Acknowledgements}

This work was financially supported by a grant from the National Creative Research Initiative program (2010-0018272) in Korea.

\section{References}

1 S. Park, M. R. Lee and I. Shin, Chem. Soc. Rev., 2008, 37, 1579-1591.

2 A. Imberty and A. Varrot, Curr. Opin. Struct. Biol., 2008, 18, 567-576.

3 (a) J. R. Bishop and P. Gagneux, Glycobiology, 2007, 17, 23r34r; (b) J. Pettersson, R. Nordfelth, E. Dubinina, T. Bergman, M. Gustafsson, K. E. Magnusson and H. WolfWatz, Science, 1996, 273, 1231-1233.

4 R. N. Pruitt and D. B. Lacy, Front. Cell. Infect. Microbiol., 2012, 2, 28-31.

5 (a) M. Mammen, S. K. Choi and G. M. Whitesides, Angew. Chem., Int. Ed., 1998, 37, 2754-2794; (b) J. J. Lundquist and E. J. Toone, Chem. Rev., 2002, 102, 555-578; (c) X. Tian, J. Pai and I. Shin, Chem.-Asian J., 2012, 7, 2052-2060.

6 (a) S. Park and I. Shin, Angew. Chem., Int. Ed., 2002, 41, 31803182; (b) D. N. Wang, S. Y. Liu, B. J. Trummer, C. Deng and A. L. Wang, Nat. Biotechnol., 2002, 20, 275-281; (c) S. Fukui, T. Feizi, C. Galustian, A. M. Lawson and W. Chai, Nat. Biotechnol., 2002, 20, 1011-1017.

7 (a) J. Y. Hyun, J. Pai and I. Shin, Acc. Chem. Res., 2017, 50, 1069-1078; (b) C. D. Rillahan and J. C. Paulson, Annu. Rev. Biochem., 2011, 80, 797-823; (c) S. Park, J. C. Gildersleeve, O. Blixt and I. Shin, Chem. Soc. Rev., 2013, 42, 4310-4326.

8 (a) O. Blixt, S. Head, T. Mondala, C. Scanlan, M. E. Huflejt, R. Alvarez, M. C. Bryan, F. Fazio, D. Calarese, J. Stevens, N. Razi, D. J. Stevens, J. J. Skehel, I. van Die, D. R. Burton, I. A. Wilson, R. Cummings, N. Bovin, C. H. Wong and J. C. Paulson, Proc. Natl. Acad. Sci. U. S. A., 2004, 101, 17033-17038; (b) S. Park, M. R. Lee, S. J. Pyo and I. Shin, J. Am. Chem., Soc., 2004, 126, 4812-4819; (c) B. Y. Xia, Z. S. Kawar, T. Z. Ju, R. A. Alvarez, G. P. Sachdev and R. D. Cummings, Nat. Methods, 2005, 2, 845-850; (d) J. C. Manimala, T. A. Roach, Z. T. Li and J. C. Gildersleeve, Angew. Chem. Int. Ed., 2006, 45, 3607-3610; (e) K. S. Ko, F. A. Jaipuri and N. L. Pohl, J. Am. Chem. Soc., 2005, 127, 13162-13163; (f) J. L. de Paz, C. Noti and P. H. Seeberger, J. Am. Chem. Soc., 2006, 128, 2766-2767; $(g)$ S. E. Tully, M. Rawat and L. C. Hsieh-Wilson, J. Am. Chem. Soc., 2006, 128, 7740-7741; $(h)$ Y. Chevolot, C. Bouillon, S. Vidal, F. Morvan, A. Meyer, J. P. Cloarec, A. Jochum, J. P. Praly, J. J. Vasseur and E. Souteyrand, Angew. Chem., Int. Ed., 2007, 46, 2398-2402.

9 (a) S. Park and I. Shin, Org. Lett., 2007, 9, 1675-1678; (b) O. Blixt, K. Allin, O. Bohorov, X. F. Liu, H. Andersson-Sand, J. Hoffmann and N. Razi, Glycoconjugate J., 2008, 25, 59-68.

10 (a) Y. F. Wang, C. F. Chang, C. Y. Chi, H. C. Wang, J. R. Wang and I. J. Su, J. Med. Virol., 2012, 84, 679-685; (b) L. M. Chen, P. Rivailler, J. Hossain, P. Carney, A. Balish, I. Perry, C. T. Davis, R. Garten, B. Shu, X. Xu, A. Klimov, 
J. C. Paulson, N. J. Cox, S. Swenson, J. Stevens, A. Vincent, M. Gramer and R. O. Donis, Virology, 2011, 412, 401-410; (c) K. C. Bradley, C. A. Jones, S. M. Tompkins, R. A. Tripp, R. J. Russell, M. R. Gramer, J. Heimburg-Molinaro, D. F. Smith, R. D. Cummings and D. A. Steinhauer, Virology, 2011, 413, 169-182; (d) M. B. Pearce, A. Jayaraman, C. Pappas, J. A. Belser, H. Zeng, K. M. Gustin, T. R. Maines, X. J. Sun, R. Raman, N. J. Cox, R. Sasisekharan, J. M. Katz and T. M. Tumpey, Proc. Natl. Acad. Sci. U.S.A, 2012, 109, 3944-3949; (e) H. Yang, L. M. Chen, P. J. Carney, R. O. Donis and J. Stevens, PLoS Pathog., 2010, 6, e1001081; (f) Z. Wu, E. Miller, M. Agbandje-McKenna and R. J. Samulski, J. Virol., 2006, 80, 9093-9103; (g) K. C. Nicolaou and H. J. Mitchell, Angew. Chem., Int. Ed., 2001, 40, 1576-1624.

11 (a) M.-R. Lee and I. Shin, Org. Lett., 2005, 7, 4269-4272; (b) A. Walz, S. Odenbreit, J. Mahdavi, T. Borén and S. Ruhl, Glycobiology, 2005, 15, 700-708; (c) Y. Y. Fei, A. Schmidt, G. Bylund, D. X. Johansson, S. Henriksson, C. Lebrilla, J. V. Solnick, T. Borén and X. D. Zhu, Anal. Chem., 2011, 83, 6336-6341; (d) C. J. Day, J. Tiralongo, R. D. Hartnell, C.-A. Logue, J. C. Wilson, M. von Itzstein and V. Korolik, PLoS One, 2009, 4, e4927; (e) J. Y. Hyun, C. W. Park, Y. Liu, D. Kwon, S. H. Park, S. Park, J. Pai and I. Shin, ChemBioChem, 2017, 18, 1077-1082.

12 (a) M. D. Disney and P. H. Seeberger, Chem. Biol., 2004, 11, 1701-1707; (b) C. L. Bell, L. H. Vandenberghe, P. Bell, M. P. Limberis, G. P. Gao, K. Van Vliet, M. AgbandjeMcKenna and J. M. Wilson, J. Clin. Invest., 2011, 121, 2427-2435; (c) M. A. Campanero-Rhodes, A. Smith, W. G. Chai, S. Sonnino, L. Mauri, R. A. Childs, Y. B. Zhang, H. Ewers, A. Helenius, A. Imberty and T. Feizi, J. Virol., 2007, 81, 12846-12858; (d) H. J. Nam, B. Gurda-Whitaker, W. Y. Gan, S. Ilaria, R. McKenna, P. Mehta, R. A. Alvarez and M. Agbandje-McKenna, J. Biol. Chem., 2006, 281, 25670-25677.

13 (a) C. Scheibe, A. Bujotzek, J. Dernedde, M. Weber and O. Seitz, Chem. Sci., 2011, 2, 770-775; (b) K. Gorska, K. T. Huang, O. Chaloin and N. Winssinger, Angew. Chem., Int. Ed., 2009, 48, 7695-7700; (c) H. M. Branderhorst, R. Ruijtenbeek, R. M. J. Liskamp and R. J. Pieters, ChemBioChem, 2008, 9, 1836-1844; (d) O. Oyelaran, Q. Li, D. Farnsworth and J. C. Gildersleeve, J. Proteome Res., 2009, 8, 3529-3538; (e) Y. Chevolot, C. Bouillon, S. Vidal, F. Morvan, A. Meyer, J. P. Cloarec, A. Jochum, J. P. Praly, J. J. Vasseur and E. Souteyrand, Angew. Chem., Int. Ed., 2007, 46, 2398-2402; (f) L. Moni, G. Pourceau, J. Zhang, A. Meyer, S. Vidal, E. Souteyrand, A. Dondoni, F. Morvan, Y. Chevolot, J. J. Vasseur and A. Marra, ChemBioChem, 2009, 10, 1369-1378; $(g)$ N. P. Pera, H. M. Branderhorst, R. Kooij, C. Maierhofer, M. van der Kaaden,
R. M. J. Liskamp, V. Wittmann, R. Ruijtenbeek and R. J. Pieters, ChemBioChem, 2010, 11, 1896-1904; (h) Y. Chevolot, J. Zhang, A. Meyer, A. Goudot, S. Rouanet, S. Vidal, G. Pourceau, J. P. Cloarec, J. P. Praly, E. Souteyrand, J. J. Vasseur and F. Morvan, Chem. Commun., 2011, 47, 8826-8828.

14 S. Park, M. R. Lee and I. Shin, Bioconjugate Chem., 2009, 20, 155-162.

15 J. Pai, J. Y. Hyun, J. Jeong, S. Loh, E. H. Cho, Y. S. Kang and I. Shin, Chem. Sci., 2016, 7, 2084-2093.

16 (a) J. Pai, T. Yoon, N. D. Kim, I. S. Lee, J. Yu and I. Shin, J. Am. Chem. Soc., 2012, 134, 19287-19296; (b) J. Pai, S. Hyun, J. Y. Hyun, S. H. Park, W. J. Kim, S. H. Bae, N. K. Kim, J. Yu and I. Shin, J. Am. Chem. Soc., 2016, 138, 857-867; (c) S. Park, M. R. Lee and I. Shin, Nat. Protoc., 2007, 2, 27472758; (d) M. R. Lee and I. Shin, Angew. Chem., Int. Ed., 2005, 44, 2881-2884.

17 H. Y. Hsiao, M. L. Chen, H. T. Wu, L. D. Huang, W. T. Chien, C. C. Yu, F. D. Jan, S. Sahabuddin, T. C. Chang and C. C. Lin, Chem. Commun., 2011, 47, 1187-1189.

18 Functional Glycomics website (http:// www.functionalglycomics.org).

19 P. I. H. Bastiaens, I. V. Majoul, P. J. Verveer, H. D. Soling and T. M. Jovin, EMBO J., 1996, 15, 4246-4253.

20 D. Vanden Broeck, C. Horvath and M. J. S. De Wolf, Int. J. Biochem. Cell Biol., 2007, 39, 1771-1775.

21 G. M. Kuziemko, M. Stroh and R. C. Stevens, Biochem., 1996, 35, 6375-6384.

22 C. S. Kim, J. H. Seo and H. J. Cha, Anal. Chem., 2012, 84, 6884-6890.

23 J. Shi, T. Yang, S. Kataoka, Y. Zhang, A. J. Diaz and P. S. Cremer, J. Am. Chem. Soc., 2007, 129, 5954-5961.

24 B. Foxman, Am. J. Med., 2002, 8, 5S-13S.

25 (a) M. A. Schembri, K. Kjaergaard, E. V. Sokurenko and P. Klemm, J. Infect. Dis., 2001, 183, S28-S31; (b) M. M. Sauer, R. P. Jakob, J. Eras, S. Baday, D. Eris, G. Navarra, S. Berneche, B. Ernst, T. Maier and R. Glockshuber, Nat. Commun., 2016, 7, 10738-10750.

26 (a) A. Covacci, J. L. Telford, G. Del Giudice, J. Parsonnet and R. Rappuoli, Science, 1999, 284, 1328-1333; (b) D. B. Polk and R. M. Peek, Nat. Rev. Cancer, 2010, 10, 593; (c) N. Uemura, S. Okamoto, S. Yamamoto, N. Matsumura, S. Yamaguchi, M. Yamakido, K. Taniyama, N. Sasaki and R. J. Schlemper, N. Engl. J. Med., 2001, 345, 784-789.

27 S. Park, G. H. Kim, S. H. Park, J. Pai, D. Rathwell, J. Y. Park, Y. S. Kang and I. Shin, J. Am. Chem. Soc., 2015, 137, 59615968.

28 N. Hage, T. Howard, C. Phillips, C. Brassington, R. Overman, J. Debreczeni, P. Gellert, S. Stolnik, G. S. Winkler and F. H. Falcone, Sci. Adv., 2015, 1, e1500315. 